Originalveröffentlichung in: The International Journal of Museum Management and Curatorship 1 (1982), S. 21-39

The International Journal of Museum Management and Curatorship (1982), 1, 21-39

(C) 1982 Butterworths

\title{
The Royal Castle in Warsaw
}

\section{The Interior}

ANDRZEj RotTermund

\section{A Museum of Interiors}

The reconstructed Royal Castle in Warsaw contains seventy-two separate interior spaces on five storeys - the cellars, ground floor, first floor, second floor and attics. In comparison with the cubic capacity of the Castle prior to 1939 , new spaces have been gained in the cellars which now occupy the entire area covered by the Castle, including that under the courtyard. Over half of the interior spaces perform technical functions or roles connected with the management of the building, such as air-conditioning, technological equipment, stores, offices, etc. The remaining interior spaces accessible to the public include: furnished halls and rooms, permanent exhibitions of works of art (e.g. the Treasury), a gallery of Jan Matejko's paintings, a display of coins and medals, an archaeological exhibition on display in the original fifteenth-seventeenth century cellars, a cinema, a coffee bar, vestibules, cloakrooms and other public amenities intended for the visitors to the Castle.

The main portion of the Castle consists of interiors rebuilt in the former architectural form, specially decorated and furnished with relics from a given period. These are interiors originating from the times of the Jagiellonians, the Vasa period and the reign of Stanislaus

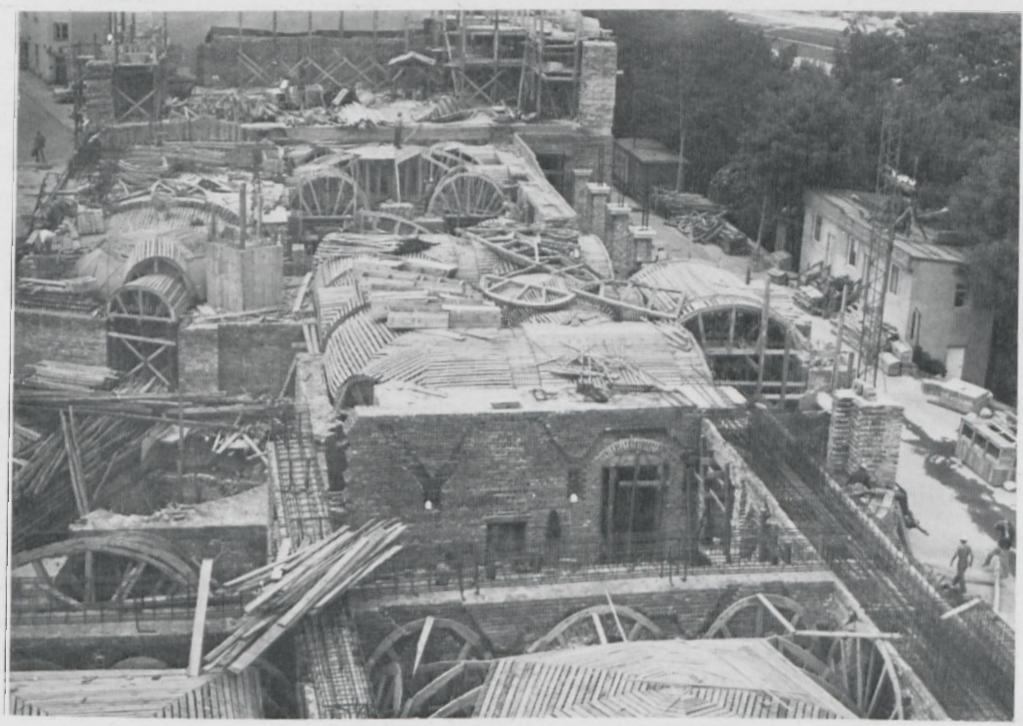

The Royal Castle in Warsaw under reconstruction, 1972. Virtually the whole of the building above ground level had been destroyed in 1944, and in its reconstruction as The Museum of Royal Castle Interiors modern building materials and techniques were employed where appropriate. 
Augustus Poniatowski. Together with the Wawel, Wilanów and Łańcut complexes, they will make up one of the richest Polish museums of historic interiors. The Castle comprises complexes of halls, chambers or rooms which played clearly defined roles during its long history. The current programme of furnishing the Castle strives to bring out these functions wherever possible and when the functions have been difficult to establish, the design adopted approaches that which the sources suggest as the most plausible. In a number of cases, interiors have recovered their historic names which had become obsolete in the nineteenth century and early in the twentieth century.

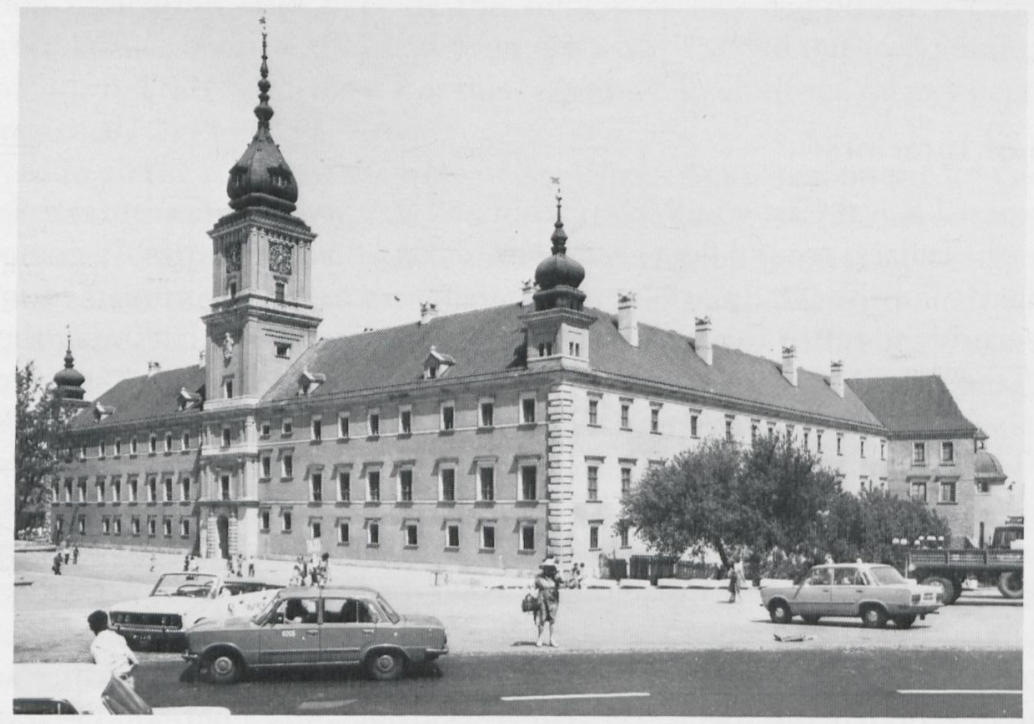

Exterior of the reconstructed Royal Castle in Warsaw with the West Façade dominated by the Grodzka Tower originally constructed by Giovanni Travano and others during the reign of Sigismund III.

The Museum of Royal Castle Interiors embraces rooms on the ground floor and the first floor. The southern part of the so-called Saxon wing on the ground floor contains a nine-room complex, which has been named the Jagiellonian Rooms. They are situated in part of the building erected during the reign of Sigismund the Old, developed by Sigismund Augustus, and adapted in the course of works ordered by Sigismund III. This complex of interiors reflects the spatial compositions favoured at the end of the sixteenth century, and the recreated decoration of the ceilings likewise refers back to the decorative style of the period. In the case of this particular complex, we are only partly familiar with the former functions of individual rooms. For instance at the turn of the sixteenth century they included the room of the Queen's maids of honour. Consequently, the design programme is related to the functional solutions adopted in other complexes of ceremonial and private rooms in Polish palaces and castles of the late sixteenth and early seventeenth centuries.

More is known about other rooms; for instance, on the ground floor of the former Greater House the Mazovian Seym (Parliament) met, and from 1572 until the close of the seventeenth century, it housed the Chamber of Deputies with which the neighbouring interiors were thus functionally related. Consequently, in addition to the Chamber of Deputies, the former Seym Chancellery has also been reconstructed. The hall preceding the Grodzka Tower has acquired the character of an interior in which the Senate Council could have sat in session during the reign of the Vasa Dynasty. The name of the room, the Medium 
Chamber, refers back to the name of the interior prior to 1569 . The interiors inside the Grodzka Tower have been given the character of a Chamber and a Study, hence their present names: the Tower Chamber and the Tower Study. The two further interiors in the eastern part of the south wing revert to their former function, both with regard to their furnishing and names; one of them is the Officers' Room and the other the Big Vestibule, formerly a passage between the Grand Staircase and the Chamber of Deputies. The furnishing of the former Seym Chancellery evokes the times of the Mazovian Dukes at the Warsaw Castle. The remaining interiors, namely, the Chamber of Deputies, the Medium Chamber, the Tower Chamber and Study, the Officers' Room and the Big Vestibule have been furnished after the Vasa fashion. A few rooms in the south-west corner, including the large Four-Pillar Room in the centre are designed as a complex of historical interiors, decorated with works of art from the times of the reign of Michal Korybut Wiśnowiecki and John III Sobieski.

The most glamorous and homogeneous complex of interiors was that decorated at the time of Stanislaus Augustus Poniatowski. It had remained in a basically unchanged spatial shape until the moment of destruction of the Castle, and the precise function of individual rooms is still remembered. The complex of Stanislavian interiors consists of: a staircase near the Grodzka Tower, the Grand Staircase, the Mier Hall also known as the Guards' Room, the Officers' Room, the Canaletto Room also known as the Room of Views, the Ante-Room to the Chapel also known as the Nave, the Chapel, the former Audience Chamber, the Royal

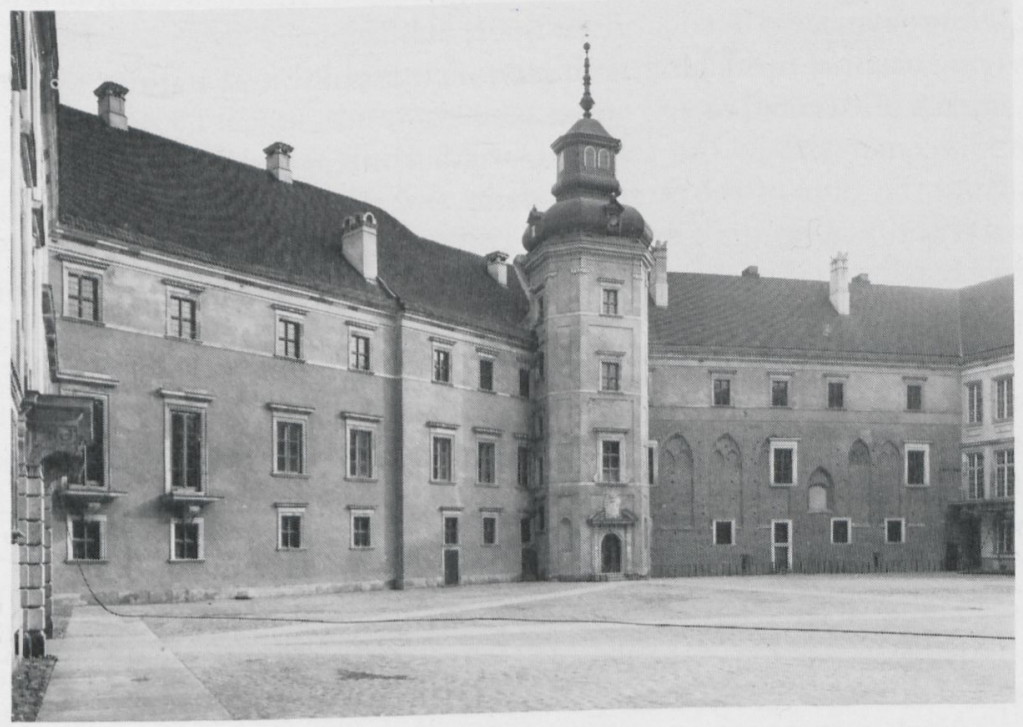

Interior of the Courtyard of the reconstructed Royal Castle in Warsaw, with the Gothic façade of the Curia Maior. Originally erected in the early fifteenth century this was covered and only revealed again in 1921.

Bedroom, the King's Dressing Room, the King's Study, the Ante-Chamber also known as the Second Dressing Room, the corridor at the back of the Former Audience Chamber and the Bedroom. Also included are the ante-room to the Green Room (which was the Council Chamber at the time of Stanislaus Augustus), the Yellow Room (used as the Dining Room at the time of Stanislaus Augustus), the Marble Study, the Throne Room, the Conference Study, the Knights' Room, the Ball Room also called the Dining Room or the Assembly Hall, and the Council Chamber. Behind the Council Chamber is a two-storey room which acted as a chapel (later, at the time of Stanislaus Augustus, it housed a theatre hall). 
A complex closely linked with the parliamentary function of the Castle, situated in the western wing, consists of the Senatorial Chamber and the adjacent Speaker's Chancelleries, the Room of the Speaker's Guard and the ante-chamber to the last mentioned; in the southern corner of the western wing there are the New Room of Deputies preceded by the Vestibule. A separate complex of interiors included the apartment of Kazimierz Poniatowski, Great Chamberlain of the Crown and brother of King Stanislaus Augustus. The apartment consists of an ante-chamber, a parlour, a bedroom, a study and a gallery-cum-corridor en suite on the side of the courtyard. The furnishing programme with regard to the apartment fully respects the former functional disposition of the complex, with the sole exception of the study which will not be reconstructed since the space where the room would be has instead been occupied by the technical equipment required.

\section{Guidelines Adopted}

The evolution of the furnishing programme for the complexes of halls, chambers and rooms here presented depends in the main on the extent of our current knowledge of these interiors. For the reproduction of the decoration of the rooms which are rebuilt in their former architectural form, suitably decorated and furnished with works of art typical of a given period, we have had a range of types of documentations at our disposal, namely:

1. the surviving original elements of interior decoration, such as details of woodwork and stucco-work, chimneypieces, details of the floor, etc.;

2. the surviving original furnishing elements, such as paintings, frames, sculptures, pieces of furniture, works of decorative art, metal fittings;

3. iconographic material in the form of original interior designs, including those for furnishings, from the time of the Saxon dynasty and the rule of Stanislaus Augustus, and inventory sheets concerning the Castle rooms;

4. iconographic material in the form of photographs of the Castle interiors from the close of the nineteenth century up to 1939 ;

5. archaeological material found on the premises of the Castle in the course of excavations carried out after 1945, e.g. tiles, chimneypieces, etc.;

6. inventories and surveys of the Royal Castle in Warsaw, in particular the inventories carried out in the times of Stanislaus Augustus in the years 1769, 1793 and 1795, and early in the nineteenth century, in 1808 and 1819 ;

7. archival material in the form of invoices for completed jobs on the decoration of the Castle rooms, mainly submitted by Marcello Bacciarelli to Stanislaus Augustus.

8. reports of diarists received at the Royal Castle in Warsaw. This extensive material acted as a basis for the decoration programme, which has been worked out by a tesm composed of Stanislaw Lorentz, Jan Zachwatowicz and Aleksander Gieysztor-representing the curatorship of the Castle, and Bożena Majewska-Maszkowska, Irena Oborska, Jerzy Lileyko (until 1977), Jerzy Baranowski (since 1976) and Andrzej Rottermund, aided by experts, mainly from the National Museum of Warsaw.

According to the range of information accessible, the interiors may be divided into four groups.

In the first group are included those interiors for which the broadest basis for reconstruction of both architecture and furnishings is accessible. We have had at our disposal original elements of decoration and furnishings in addition to good photographic documentation with, in a number of cases, original designs for decoration and, finally, complete archival information, mainly documentary. Here we can include: the Grand Staircase, the Mirowski Hall, the Ante-room to the Chapel, the Royal Chapel, the Canaletto 
Room, the King's Bedroom, the Throne Room, the Conference Room, the Knights' Hall, the Ball Room and the Marble Cabinet.

To be included in the second group are those interiors the reconstruction of which has been based only on architectural plans and measurements, as well as photographs taken before 1939; whereas they have been furnished on the basis of inventory data, archival material including mainly accounts of artisans for the work they did, or our knowledge of how an interior performing a given function was furnished in a given historical period. In this case we have used the iconographic material referring to Polish sixteenth-eighteenth century interiors. The list of interiors furnished along these principles includes: the complex of Jagiellonian Rooms, the Former Seym Chancellery, the Chamber of Deputies, the Medium Chamber, the Tower Study, the Tower Chamber, the Officers' Room, the Big Vestibule, the complex of interiors in the south-western corner on the ground floor, the Senatorial Chamber, the Speaker's Chancelleries, the Room of the Speaker's Guard, the Council Chamber, the Theatre Hall (formerly the Saxon Chapel), the King's Study, the King's Dressing Room, the staircase in the Ladislaus Tower, and the staircase near the Sigismund Tower.

Included in the third group are those interiors with regard to which no elements of the original decoration and furnishings have survived and there is no documentation in the form of old architectural designs and measurements. The interiors of this group include also those, the decoration and furnishing of which prior to 1939 were quite haphazard and artistically unsatisfactory. Hence it has been decided that they are not to be reconstructed in that shape in the course of the present rebuilding. Among these are: the so-called Ante-chamber, the Yellow Room, the Green Room, the ante-room to the Green Room, the Rooms of the Prince Chamberlain, the Ante-chamber to the New Chamber of Deputies, and the so-called Vasa Gallery in the northern wing on the side of the courtyard.

In the fourth group are included those interiors which did not exist in the historic days of the Castle in their present architectural shape. They have been introduced in the course of the current reconstruction mainly for functional reasons, though in accordance with the former spatial arrangement of the building. These are: the corridor at the back of the Former Audience Room and the King's Bedroom (in the past divided into a few auxiliary interiors), the staircase near the Theatre Hall (Saxon Chapel), the gallery near the Council Chamber (started already before the war, though without the stairs) and the oval staircase near the Ball Room (in the past there was only a narrow auxiliary staircase there.

\section{Interiors of the First Group}

The decoration of interiors of this group was based on the photographic documentation prior to 1939 , inventories carried out in the Castle in the years 1793,1795 and 1808 and account sheets concerning work done in the first-floor rooms during the reign of Stanislaus Augustus. Also accessible were original elements of interior decoration and surviving works of art originally placed in these interiors. In a number of cases use has been made of old architectural sketches referring to the interiors in question. The final purpose of the relevant study has been a programme as close as possible to the artistic and thematic concepts of the interiors when they were originally furnished. The programme embraced first of all those objects with which a given interior was decorated and which have survived until this day in museum collections. It includes also objects which have not survived, have been lost or are not accessible to those in charge of the programme (mostly purchased by foreign collectors via Russia in the nineteenth century and preserved in foreign museums and private collections). The missing objects can be divided into three groups: those which can be 
reproduced on the basis of the surviving originals (these are sets of identical objects with individual items surviving and therefore incomplete); the second group comprises articles which are known from a description in an inventory sheet and can be replaced by others, whose style and workmanship is reminiscent of the missing ones; the third group comprises those which are known only from description but cannot be replaced either from a museum collection or by way of purchase. In that case it has been decided that a copy should be made, patterned upon an original object, related to the one present in a given room in the past and mentioned in inventories (most usually it is a question of a dozen or so identical pieces).

An analysis of the Canaletto Room will illustrate the method leading to the furnishing programme of an interior rebuilt in its former architectural shape, appropriately decorated and furnished with relics of art originating partly from the room. The starting point was an analysis of three inventories.

1. 'The inventory of the furniture and other accessories in the Castle of HRH the King and

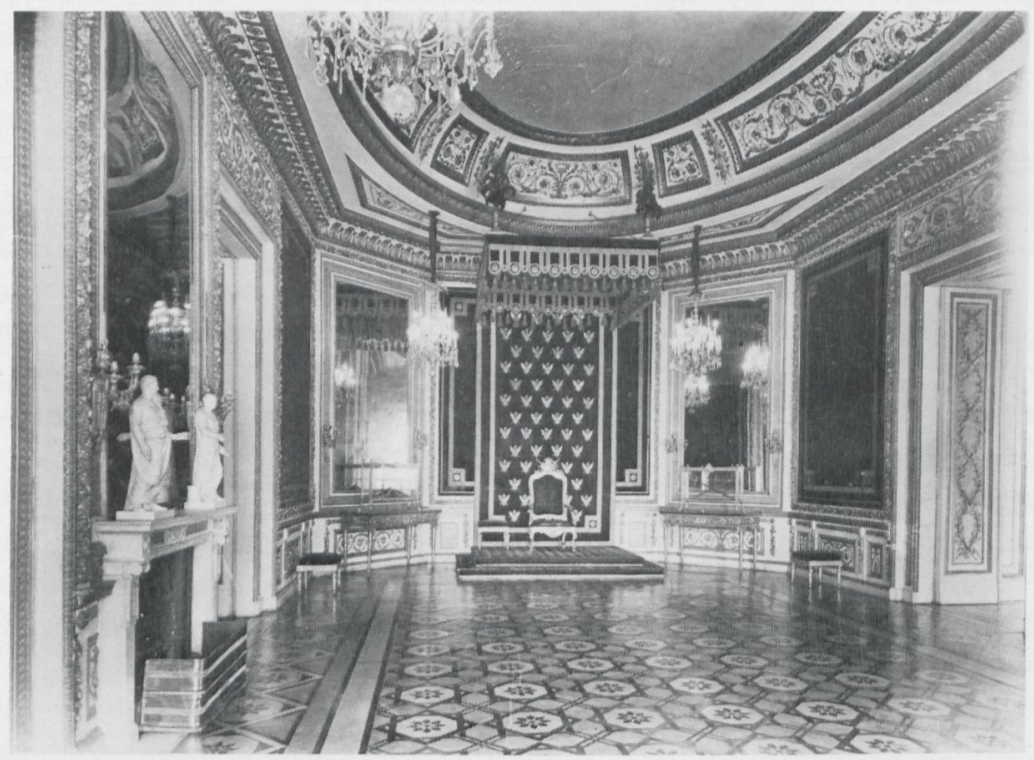

Throne Room of the Royal Castle in Warsaw dating from the reign of Stanislaus Augustus Poniatowski, before its destruction.

the Commonwealth, put down in 1793,' mentions the following items in the Canaletto Room, referred to in the inventory as the 'Ante-room to the Chapel':

'the wall-covering makes up a panorama of views of 22 pieces.

1 hanging crystal chandelier with bronze

2 mirrors composed of two pieces each

a clock above the mirror

1 small marble table on carved, gilded legs

10 small gilded bronze wall sconces

2 settees upholstered in flower-patterned "Kamelhaar Plüsch", with no arms

8 stools upholstered in the same fabric

4 cotton curtains

2 boxes to keep wood in

a wire grating in front of the fireplace

1 pair of fire-irons.' 
The following items are mentioned in the 'Inventaire Général des Meubles et Effets mobiliers, qui sont dans le Château de Varsovie, fait en Mars 1795', much more precise with regard to the furnishing but making no mention of the paintings:

2. 'Un chambranle de cheminée de marbre, couler grisâtre mêlée. Dans l'interieure de la cheminée 2 plaques de cuivre rouge et une de fer

Deux chenêts de fer et un garni en fil de laiton, le tout vieux

Un grand trumeau de glace composé de 2 pièces sur la cheminée, haut de 4 aunes et 7 pouces, sur deux aunes et 4 pouces de large

Un autre trumeau de glace entre fenêtres composé de deux pièces, de 4 aunes de hauteur, sur une aune et 15 pouces de large

Une table en demi-cerle a 4 pieds dorés avec un dessus de marbre blanc

Dix bras a 3 branches, avec un petit vason posé sur une gaine, entortillés des festons le tout de bronze doré en ormoulu a 25 . la pièce

Throne Room of the Royal Castle in Warsaw after reconstruction and before furnishing. The fragments of original mouldings incorporated can be clearly seen.

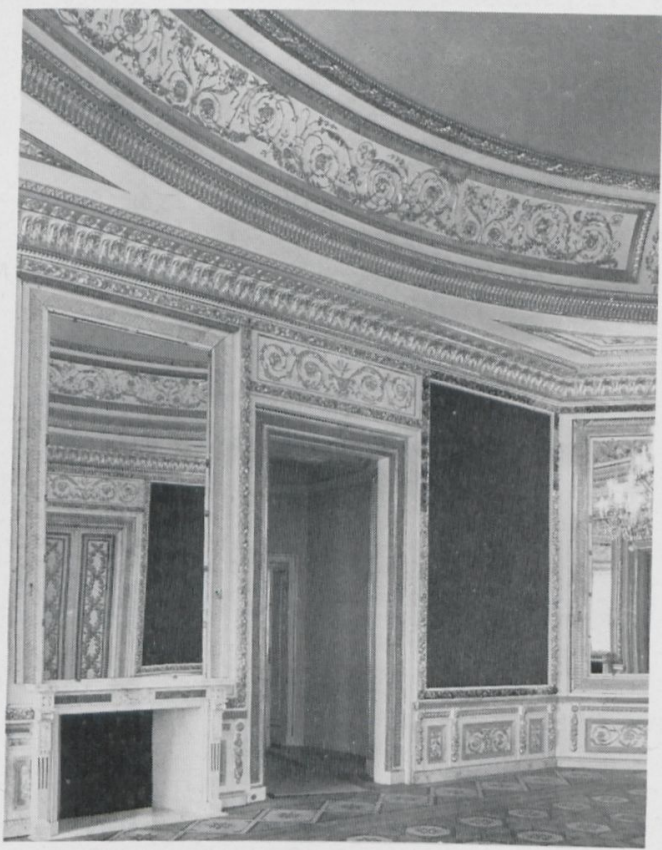

Un mouvement de pendule incrusté dans le trumeau au dessus de la cheminée Quatre rideaux de toile aux 4 fenêtres déjà vieux

Un Lustre de cristal de Bohème a 8 bobèches, dont la carcasse est dorée, avec un cordon et les glands qui suspendent

Quatre tringles de fer pour garantir les tableaux, polier et couleur d'eau

Deux grandes banquettes et 8 tabourets en bois couleur de noier, couvert de tapis de savonnerie, déjà vieux.'

3. These two inventory sheets are complemented by the 'Inventory of furniture and various other effects in HRH the King's Castle in Warsaw, specifying to whom a given piece of furniture or effect belongs, written down by the undersigned Fiskul, a member of the Prefecture of the Department of Warsaw, in 1808':

'a chimneypiece of grey marble, known as Brescia, two copper and one iron sheets inside the fireplace; fire-irons with pincers, a shovel and tongs 
1 screen in front of the fire, stained, with brass rosettes, upholstered in green silk and lined with an orange paper border

1 mirror trumeau, composed of two pieces, 4 ells and 7 inches high and 2 ells and 4 inches wide

another mirror trumeau, likewise of 2 pieces, 4 ells high and 1 ell and 15 inches wide

1 semicircle table on 4 wooden gilded legs, covered with white marble

1 clock above the trumeau in front of the fire;

6 muslin flounced curtains

1 chandelier of Bohemian crystal, with a brass semicircle bail for 8 candles

4 iron bars for the protection of the wall-covering

10 three-branched wall sconces, with a vase in the upper part, decorated with festoons, all made of gilded bronze

1 alder box, stained

12 English mahogany chairs, covered in cloth

2 big table chairs, stained, upholstered in blue damask

1 white varnished settee, stuck with small yellow nails, with a mattress, two cushions and the sides and the back upholstered in green and white striped silk

Paintings by Canaletto

The view of the Governmental Palace, No 425

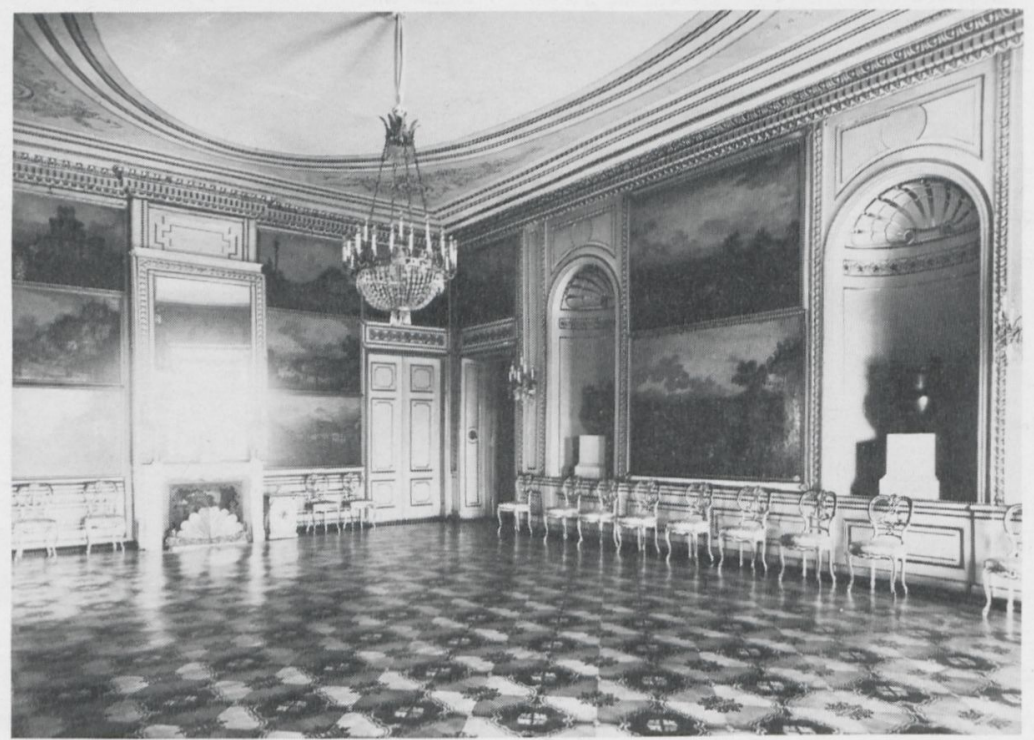

Canaletto Room of the Royal Castle in Warsaw prior to 1939. Bernardo Bellotto, known as Canaletto in Poland, was Court Painter to Stanislaus Augustus and this room was decorated with a cycle of 22 large views of Warsaw by him.

The View of Wilanów, as seen from the Belvedere by Canaletto, No 424

The View of the Mniszech Palace, ditto, No 1185

The View of the Lubomirski Palace behind the Iron Gate, ditto, No 1184

The View of the Church of the Nuns of the Visitation, No 1183

The View of Wilanów by Canaletto, No 429

The View of the Church of the Capuchins in Krakowskie Przedmieście, ditto, No 482 (a note in pencil: the wrong number, No 1182) 
The View of Wilanów, as seen from the garden, No 433

The View of the Arsenal and Holy Trinity Church, No 428

The View of the Czartoryski Palace, No 1181

The View of the Kapucyńska Street, now Napoleon Street, as seen from Senatorska Street, No 439

The View of the Church of the Nuns of the Holy Sacrament in New Town, No 430

The View of Wilanów, as seen from the Wilanów Courtyard, No 437

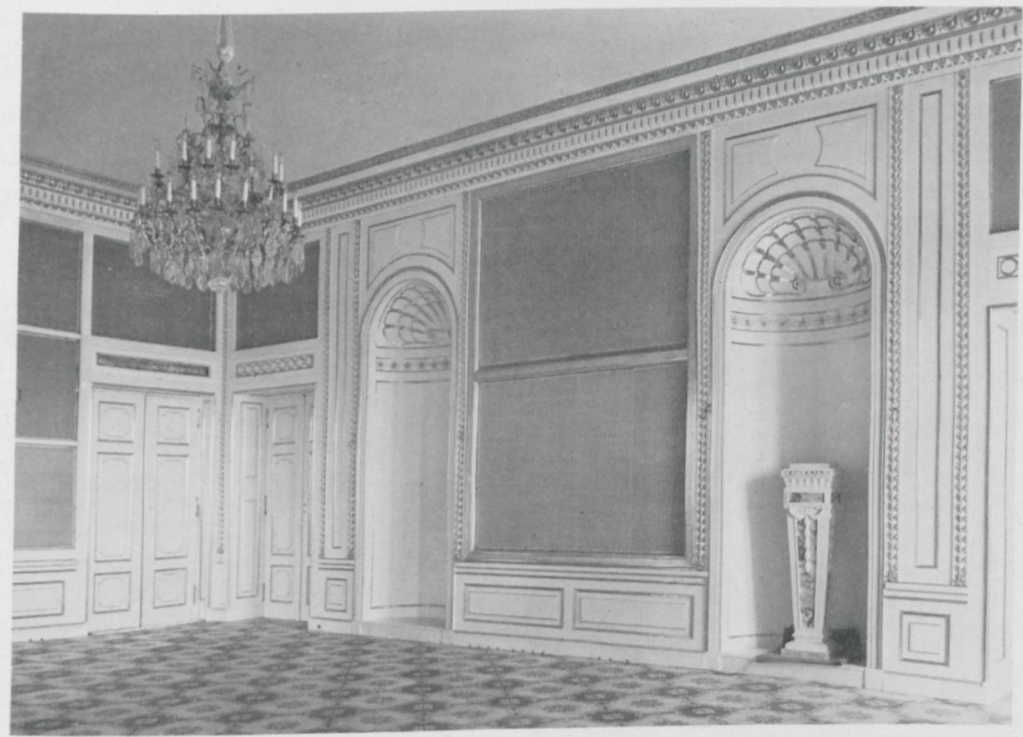

Canaletto Room of the Royal Castle in Warsaw after reconstruction and before furnishing. The set of paintings survived and are at present in the National Museum, Warsaw.

The View of Warsaw, as seen from the Ordynacki Palace, No 436

The View of the Reformed Fathers' Church, No 1180

The View of Dluga Street, as seen from New Town, No 442

The View of Krakowskie Przedmieście, as seen from the Black Friars Church, No 441

The View of the Wilanów Palace, as seen from the lower garden, No 443

All by Canaletto.'

An analysis of the three inventories shows that during the reign of Stanislaus Augustus, the Canaletto Room contained a marble chimneypiece, with a mirror above it and, higher up, above the mirror, a built-in clock. Beside the fireplace there were two boxes to keep wood in (only one box in 1808), a chimney screen and a set of fire-irons. There was also a mirror between the windows on the wall on the Vistula side. On the wall panelling there were twenty-two paintings by Bernardo Bellotto who was known as Canaletto in Poland. Their original arrangement (i.e. the sequence in which they hung) could be reproduced on analysis of the inventory of 1808. By the walls there were eight stools and two banquettes, described in the 1793 inventory as 'settees with no arms' (before 1808 the stools and the banquettes were replaced by fourteen chairs and a white varnished settee). Between the windows there was a gilded console-table. The room was illuminated by ten three-branched ormolu sconces attached to the frames of Canaletto's paintings. From the ceiling hung an eight-candle chandelier decorated with Bohemian crystal. There were linen curtains on the windows and 
the door to the nave in front of the chapel. In the case of the Canaletto Room, the information contained in the inventories was complemented by the measurement of the first floor of the Castle, carried out in 1808 by Hilary Szpilowski. We see there two niches in the wall adjacent to the Former Audience Room where two stoves, circular in projection, have been indicated. The documentary photographs of the redecoration carried out in the Castle in the 1920s, demonstrate that these niches reached as low down as the floor.

Of the objects originally furnishing the Canaletto Room, the following have survived in the collection of the National Museum in Warsaw:

6 three-branched ormolu sconces

22 paintings by Bernardo Bellotto known as Canaletto

1 semicircular gilded console-table

1 wooden box to keep wood in.

The objects rescued in 1939 and 1940 included large fragments of the chimneypiece from that room.

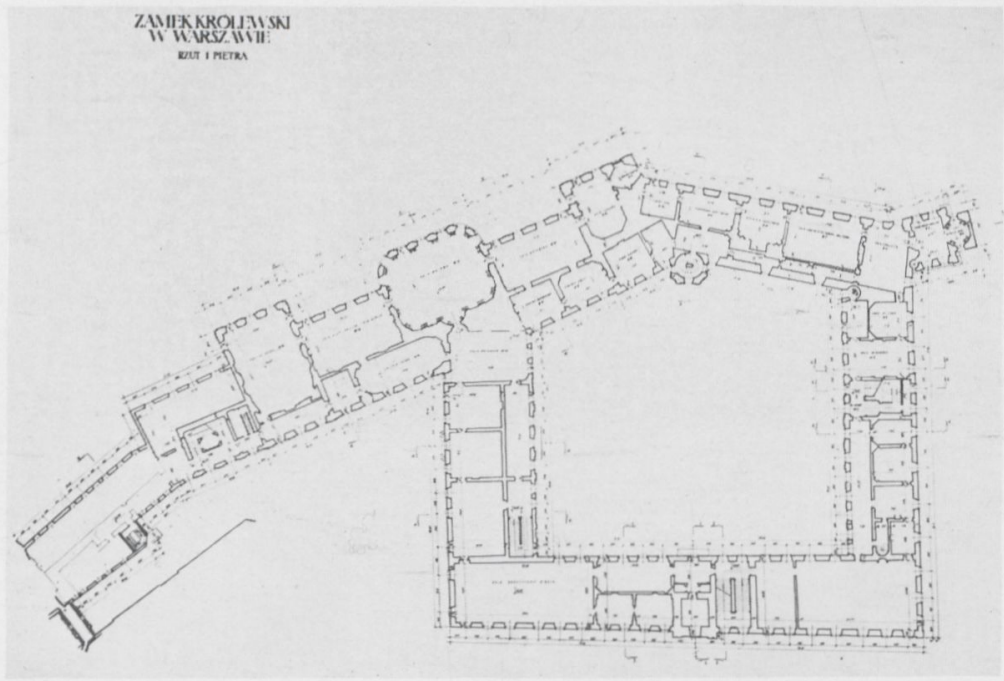

Plan of the First Floor of the Royal Castle in Warsaw.

The elements missing from the furnishing as it was at the time of Stanislaus Augustus include:

4 three-armed ormolu sconces

a set of fire irons

a built-in clock

2 banquettes

8 stools

muslin curtains

silk draperies

two mirrors: above the chimneypiece and between the windows.

Only with regard to the three-branched sconces could the six surviving items of the set act as models. The four faithful copies made on the basis of the model are not different from the original ones.

From the collection of the National Museum in Warsaw and from the donations for the Castle, an original crystal chandelier has been chosen and a set of fire irons. It was not 
possible to come by original eighteenth century stools and banquettes since furniture was always designed so as to strictly harmonize with a given interior. In this particular case, sketches were worked out on the basis of patterns provided by experts, and the reconstruction of the furniture was commissioned accordingly. The same method was adopted with regard to curtains and draperies: a suitable pattern was selected amongst late eighteenth century fabrics and this was followed by reconstruction. Likewise the mirrors above the chimneypiece and between the windows have been reconstructed, strictly in accordance with eighteenth century principles of mirror design. For the time being, the idea of placing a clock above the chimney mirror has been given up, and the same applies to a copy of another wood-box. The place of the stoves which have not survived will be occupied by eighteenth century statues of Flora and Fauna or late eighteenth century vases. The inventories of the late eighteenth century and that of 1808 do not mention any objects on the console-table or the mantel-piece. As it was almost a rule at that time to have clocks, sets of vases, candlesticks,

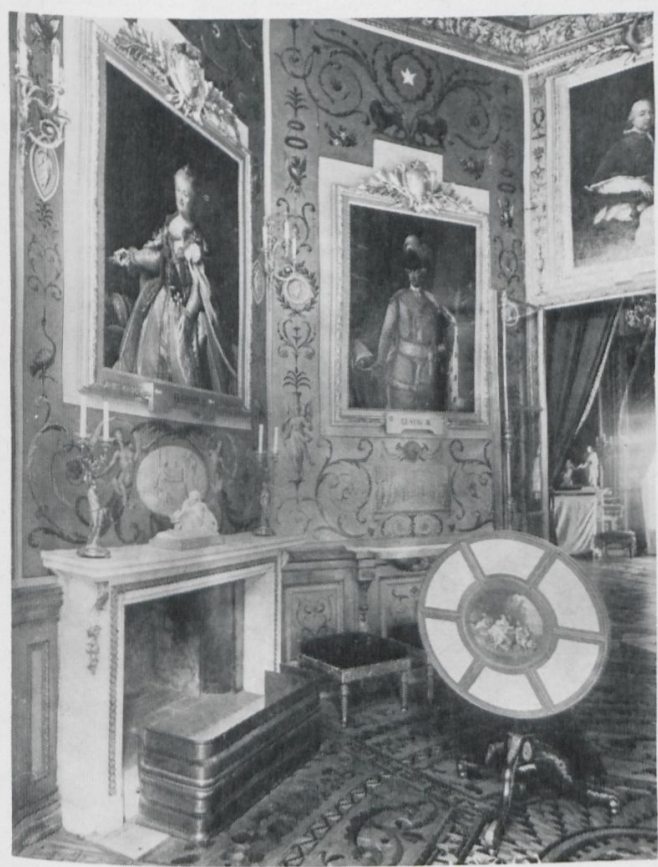

Conference Room of the Royal Castle in WarSaw prior to 1939 , with portraits by Marcello Bacciarelli and others. Photographs such as these were valuable sources of information.

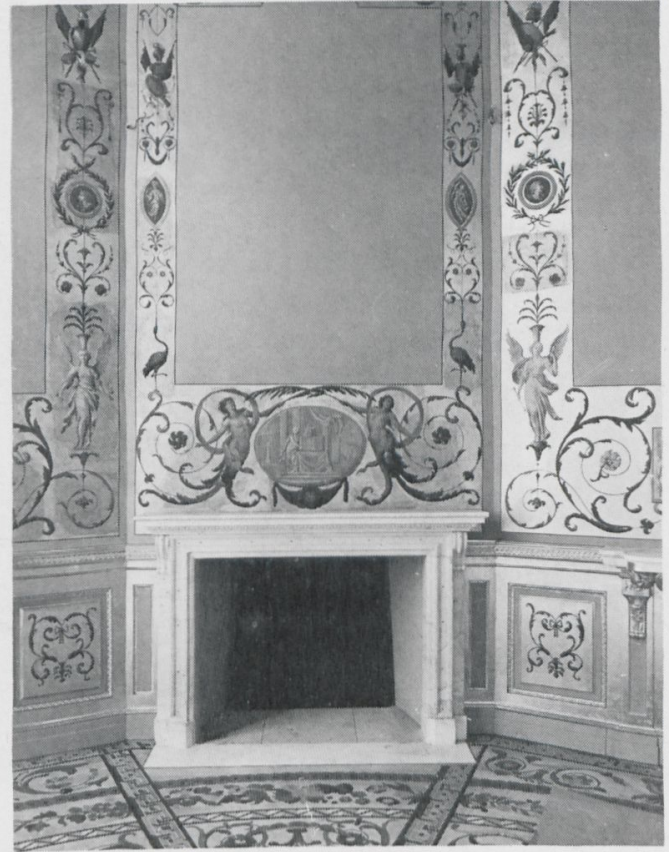

Conference Room of the Royal Castle in Warsaw at an advanced stage of the reconstruction. Clearly visible are the sections of painting rescued before the Castle was blown up.

etc. on console-tables and mantel-pieces, it has been decided that the furnishing programme for the Canaletto Room will include a clock on the console-table and a set of neoclassical alabaster vases on the mantel-piece.

The outcome of the analysis of the inventories, archival photographs taken prior to 1939 , the 1808 measurement of the Castle and, first and foremost, objects originating from the Canaletto Room was the final programme for the furnishing of the room. It includes:

1 marble chimneypiece

1 mirror above the chimney

1 mirror between the windows 
1 crystal chandelier

10 three-branched sconces

22 paintings by Bernardo Bellotto known as Canaletto

1 semicircular console-table

1 wooden box to keep wood in

1 set of fire irons

1 set of marble vases

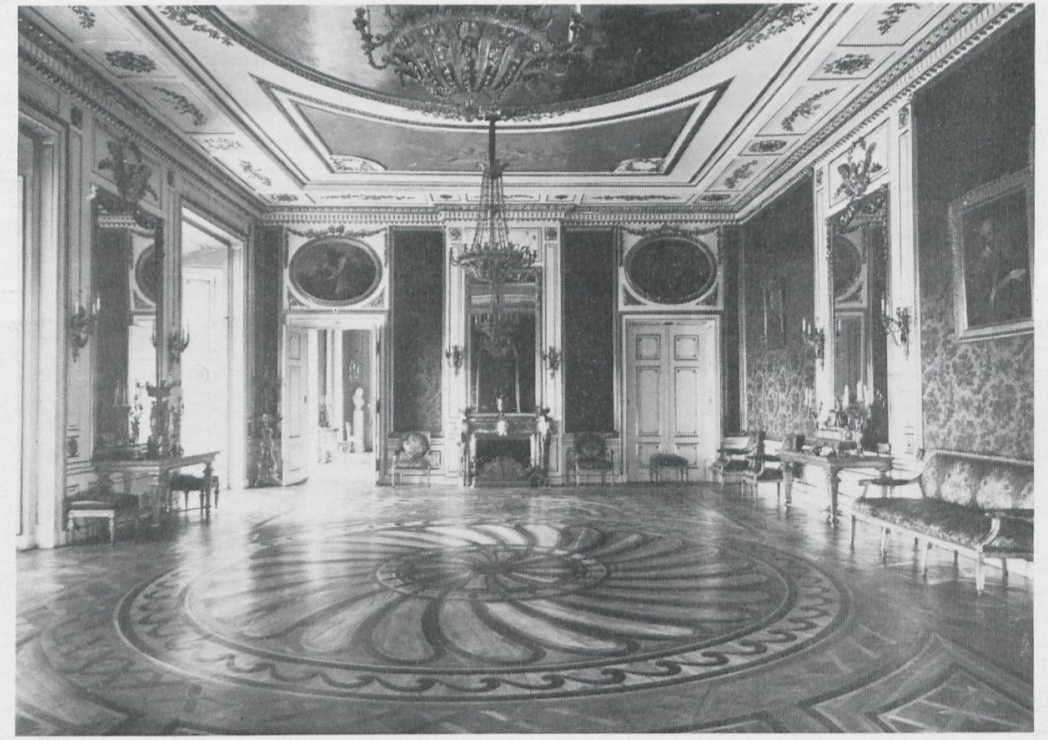

Audience Room of the Royal Castle in Warsaw prior to 1939. This room, dating from the reign of Stanislaus Augustus, was then lit with two large chandeliers.

1 bronze clock

a statue of Flora (or a vase)

a statue of Fauna (or a vase)

2 banquettes

8 stools

2 plinths

4 muslin curtains

4 silk draperies

\section{Interiors of the Second Group}

When no original elements of interior design and decoration have survived, we have reconstructed the original appearance of an interior using archival photographs taken prior to 1939, drawings of architects employed by Stanislaus Augustus, architectural measurements carried out in the Castle interiors in the past and archival materials of different types. In this situation we can distinguish between two basic variants: one, when on the basis of old photographs and measurements the architectural design of a given interior can be reproduced, and we know its function from source materials and what we lack is concrete data as to the original furnishings (this applies to the former Chamber of Deputies in the Greater Court). The other variant applies to interiors with regard to which we can reproduce the architectural design on the basis of original architectural drawings, and the same applies to 
some part of the furnishing and, in addition, we have at our disposal inventories describing the furnishings. Those were the data accessible with regard to the King's Dressing Room and Study.

We shall illustrate the furnishing programme described here as the first variant, using the example of the Former Chamber of Deputies. It was rebuilt on the basis of pre-war inventories and photographs. In decorating the room, we tried to bring out its original functions as precisely as possible. The walls have been covered in plaster, painted purple and the floor in dark red terracotta. The decoration of the eastern part of the room strictly follows the existing descriptions and iconographic information concerning the appearance of the Chamber of Deputies. The programme of decoration includes objects associated with its former function: an armchair for the Chamber's Speaker, a table and two chairs for the scribes. Both the armchair, the chairs and the table are original late sixteenth century objects. The table is covered with an original oriental carpet. There are eighteen reconstructed benches round it, upholstered in red cloth. The benches were modelled after furniture of that type occurring in Polish paintings and prints of the sixteenth century. They are usually simple wooden constructions, with cloth loosely hanging from them. Likewise reconstructed are eight brass chandeliers, patterned after the seventeenth century chandelier from the National Museum's collection. Another reconstruction is the stove, reproduced on the basis of original tiles of Sigismund III's times, excavated on the premises of the Castle.

In order to conjure up the former function of the room, portraits of State dignitaries, among others Seym Speakers and Deputies, have been hung on the walls. They include

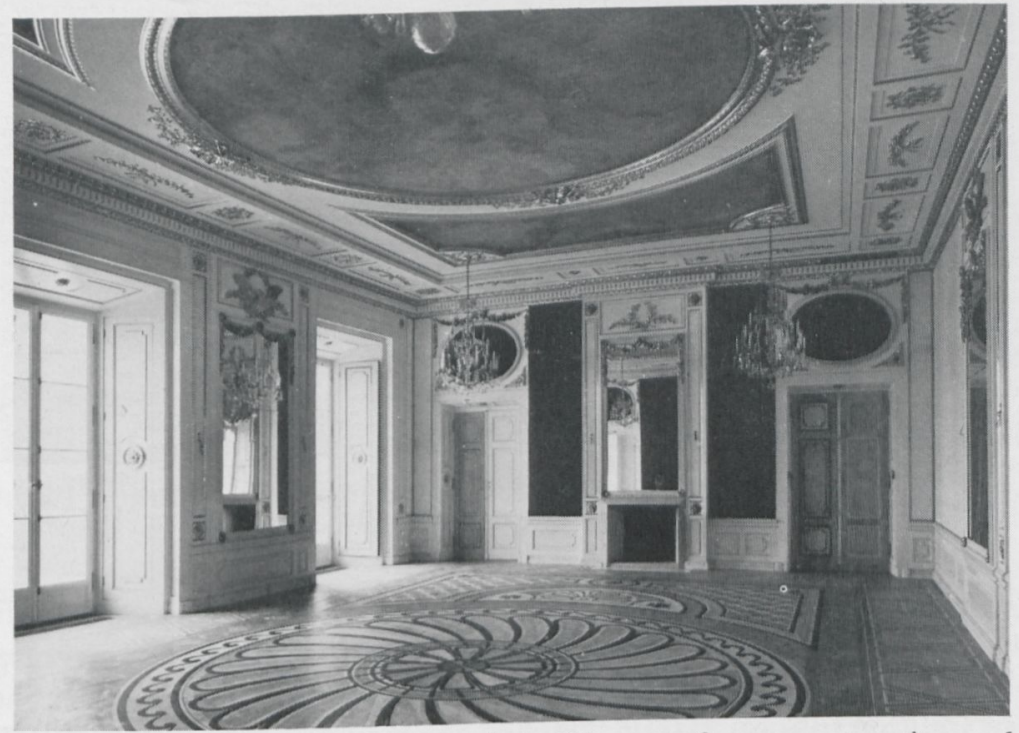

Audience Room of the Royal Castle in Warsaw after reconstruction and before furnishing. The repainting of the ceilings, yet to be undertaken, poses major problems.

portraits of Stanislaw Lubomirski, the Voivode and Starost (Prefect) of Cracow; Marcin Tyszkiewicz, the Royal Marshal of Lithuania from 1589; Jerzy Sebastian Lubomirski, the Grand Marshal of the Crown in 1658; Antoni Tyszkiewicz, the Lithuanian Marshal of the Court from 1645; Aleksander Michal Lubomirski, the Voivode of Cracow and the Deputy of Sandomierz; Piotr Skarga, the Seym Preacher; Dominik Mikolaj Radziwill, the Grand Lithuanian Chancellor; Stefan Pac, the Lithuanian Deputy Chancellor of the Treasury from 1635; Wasyl Tyszkiewicz, the Royal Marshal from 1546; Jan Kazimierz Krasiński, the 
Deputy of Ciechanów and the Grand Royal Treasurer in the years 1658-1668; Stanisław Krasiński, the Constable of Plock from 1653; Jan Dobrogost Krasiński, the Deputy of Ciechańow, from 1668 the Starost of Warsaw and from 1688 the Voivode of Płock; Stanislaw Bonifacy Krasiński, the Starost of Warsaw from 1700 and the Constable of Plock from 1712.

The King's Dressing Room and Study will illustrate the second variant employed with regard to interiors of the group here presented. In the course of the present reconstruction of the Castle, we have had recourse to Jan Chrystian Kamsetzer's design which served as the basis for the decoration of these particular interiors. The decision grew from the conviction that in the sequence of Stanislavian rooms, interiors so closely linked with the person of the King ought to look as they did at the time of his rule, and the only material at our disposal consisted of Kamsetzer's drawings. It must be remembered that the Royal Study was completely redecorated early in the nineteenth century when new wall paintings were added, whilst in the 1920s numerous elements and details were again altered. We saw no point in returning to the immediately pre-war situation.

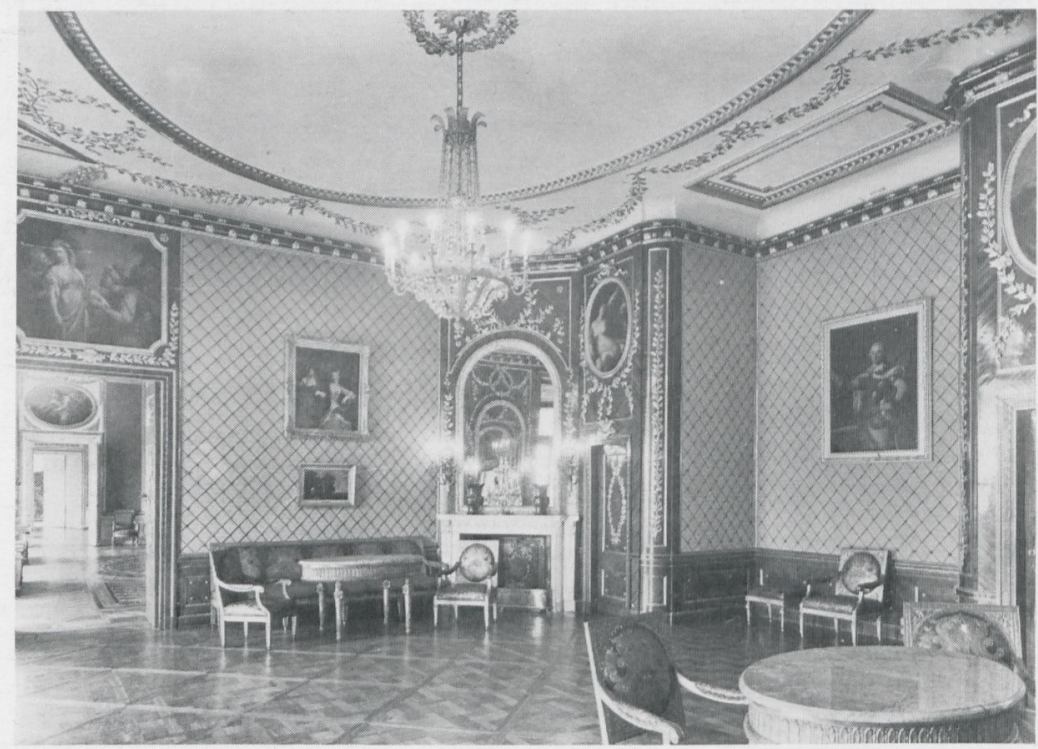

Former King's Bedroom of the Royal Castle in Warsaw, prior to 1939 , when it had been turned into a drawing room.

The interiors designed by Kamsetzer have the character of a picture gallery, with paintings in heavy frames providing the basic compositional elements and the architecture acts merely as a simple and unimposing background. The basis for the decoration of these interiors consisted of in addition to Kamsetzer's sketches, the inventories of 1793 and 1795 . The latter illustrates the atmosphere of the private Royal interiors which stood in sharp contrast to the ceremonial rooms: while the latter were restrained and disciplined, the former were crammed with furniture, paintings and various small objects. This is best illustrated by the inventory of the King's Study and Dressing Room carried out in 1793. The following items were found in the Study:

'2 settees with arms, upholstered in green striped silk, with canvas covers

6 chairs upholstered in the same silk with canvas covers

1 chair with arms, upholstered in green leather

2 big chests of drawers, each with 3 drawers, with bronze metal fittings on the top of the chests 
2 ash-wood tables covered in green cloth

1 ash-wood table for writing in the standing position

1 veneer chest of drawers, with bronze elements and a marble top

12 vases of Belvedere faience on plinths

2 vases of Chinese faience on the chest of drawers

2 mirrors, one of them containing a clock

double curtains: of green striped silk and of white linen

1 hanging lantern with ormolu decorations

2 alabaster figures on the chest of drawers under the mirror

2 ditto on the chimneypiece, with bronze sconces

1 clock in a glass casing, on the chimneypiece

3 bronze figures on the chimneypiece

2 ditto, of white alabaster, lying, in glass cases

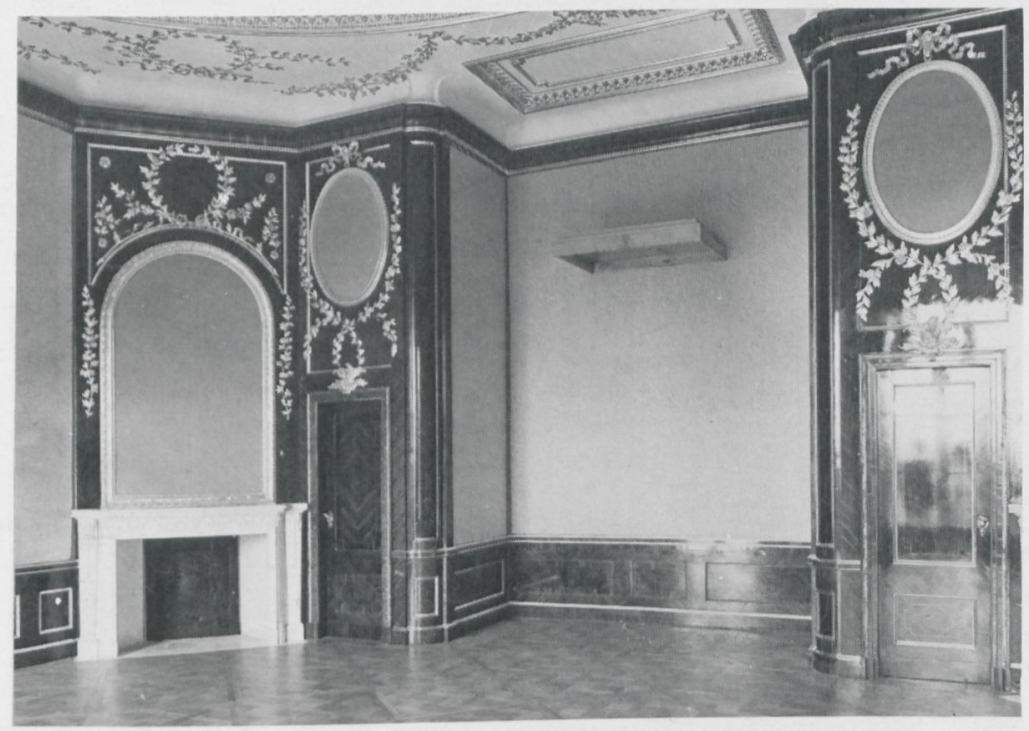

King's Bedroom of the Royal Castle in Warsaw at a late stage in the reconstruction. No attempt has been made to reconstruct the room to its pre-1939 appearance, and instead the King's bed has been reconstructed to be placed in the alcove.

2 stone busts on the chest of drawers, each with two faces an image of death, made of wood, in a glass vessel on the chest of drawers 2 small alabaster containers, with bases of black marble on the chest of drawers

3 faience plates on the chest of drawers

3 small bronze sconces with china garlands

2 tin screens upholstered in silk

1 ditto, in stained frames, of green silk

1 ditto, embroidered on white silk

a big mahogany desk, upholstered in black leather, with bronze fittings

a small mahogany desk, with a screen

1 chaise long, upholstered in red cloth, covered in red linen

a linen folded screen, painted on one side and with a map stuck to the other. The map has the shape of a door-curtain. 
2 small boxes of yellow tin, to keep saw-dust in

2 stands

1 iron guéridon with sconces

a couple of bronze fire utensils

iron tongs, a shovel, small leather bellows, a wire gallery-shaped net by the fire'.

In the case of the Dressing Room, the inventory mentions:

' 2 mirrors, one of 6 pieces over the fire, the other of 2 pieces

1 hanging crystal chandelier with a bronze element

6 small bronze sconces on the walls

1 clock hanging above the mirror

1 veneer chest of drawers, with 2 drawers, bronze fittings and a marble top cotton curtains on the 2 windows

1 faience vase on the chest of drawers

12 mahogany chairs upholstered in red leather

2 ash-wood tables, covered in green cloth

1 mahogany table, upholstered in leather

2 small stained chests of drawers

1 small stained table with a chest of drawers

2 screens of green cloth for the boudoir

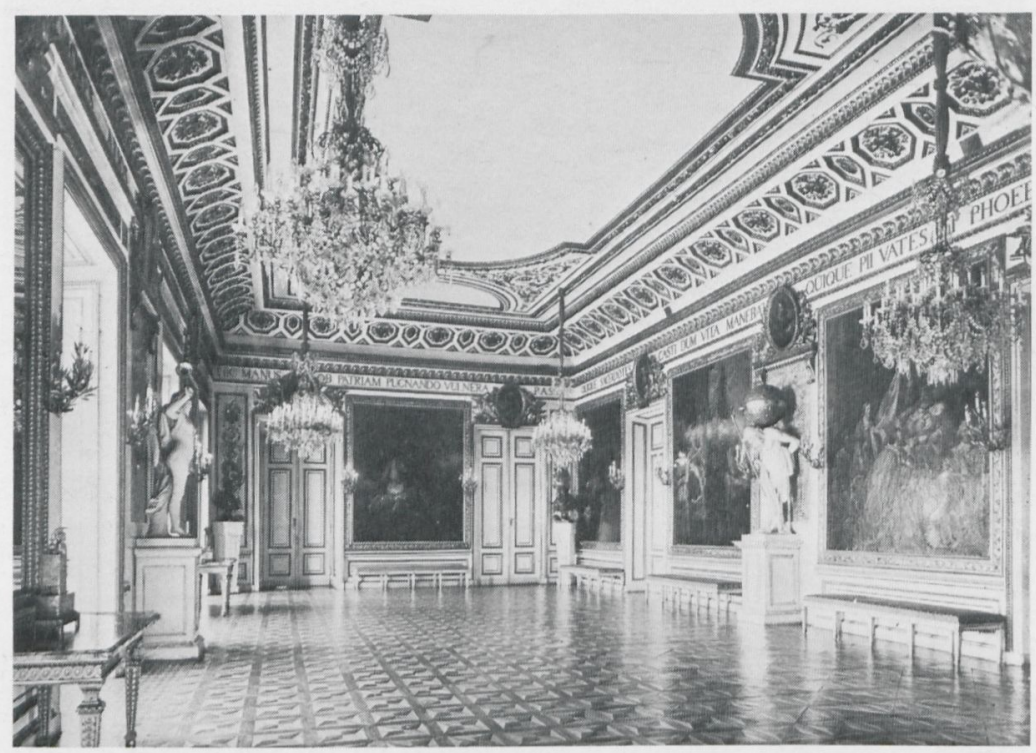

Knight's Hall of the Royal Castle in Warsaw, prior to 1939, revealing the alterations to the room undertaken during the nineteenth century.

\section{7 different paintings}

1 ash-wood chair with a linen cover

1 tin screen

1 ditto, stained frames, folded, green

a barometer

a pair of bronze fire utensils

1 shovel and iron tongs

a gallery-shaped wire net by the fire, a spittoon of yellow tin'. 
The decoration programme for the Dressing Room aimed to convey the atmosphere of these interiors as it was in the times of Stanislaus Augustus. Consequently two late eighteenth century wardrobes have been placed by the western wall of the Dressing Room with clocks with Chronos figures, two small neoclassical vases and small bronze figures of a Negro and Negress on them. Between the windows, a neoclassical chest of drawers has been placed, and on it a clock with a marble case and a pair of marble censers with bronze mounts. In the corners of the room are two marquetry escritoires and on both sides of the wardrobes there

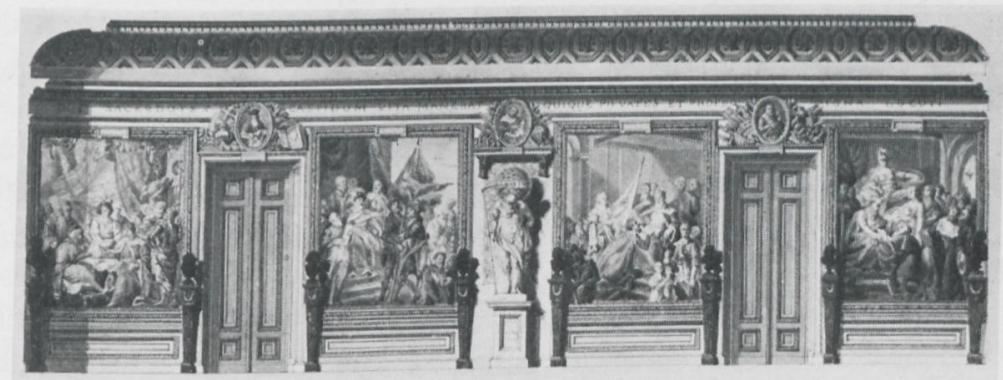

Knight's Hall of the Royal Castle in Warsaw as recorded in the Inventory of 1808. The Inventory drawings have been a major source of evidence for the reconstruction of rooms which had been altered during the nineteenth century.

are bronze candelabra with eagles set on plinths and a pair of vases in the style produced by $\mathrm{K}$. Wolff's factory in Warsaw. Against the wall adjacent to the Bedroom there is a classicist long case clock of the late eighteenth century. In the Study there is a Louis XVI desk, made by the renowned cabinet maker David Roentgen, and an armchair; between the windows a neoclassical chest of drawers with a pair of vases (produced by the Belvedere factory) on it. Around the walls, a set of neoclassical furniture comprising a settee and six armchairs has been arranged, and on the mantel-piece there is a clock with the figure of Cupid and on both sides a pair of French Candelabra made to Falconet's design. The walls of the Dressing Room and the Study are covered in green ribbed silk, acting as a background for sixty paintings in frames copied from the original frames from Stanislaus Augustus's gallery. Paintings for the Study have been selected from amongst the canvases of painters closely associated with Stanislaus Augustus, namely, Marcello Bacciarelli, Jan Bogumil Plersch, Franciszek Smuglewicz, Per Krafft, Kazimierz Wojniakowski, Jean Pierre Norblin de la Gardière, Jan Scislo and Jean Pillement. The paintings in the Dressing Room come from foreign schools and their subjects are as reminiscent as possible of those hanging there in the $1790 \mathrm{~s}$. Both interiors are lit by chandeliers reconstructed after the originals designed by Jan Chrystian Kamsetzer.

\section{The Third Group of Interiors}

The only reliable source for working out the decoration programme for the interiors of this group was provided by the inventories. In this situation, two solutions have been sought with regard to both decoration and architecture. One consists of adopting a neutral composition for the architectural design, based on popular schemes of classicising interior design. Decoration to match can be derived from that employed in the past, as revealed by the inventories. The chief consideration has been that they should have a well-defined functional 
character. This method has been adopted while planning the decoration and furnishing programme for the Ante-chamber known as the Second Dressing Room, the Yellow Room, the Green Room, the Ante-room to the Green Room and the vestibule to the New Chamber of Deputies. In the case of the Ante-chamber, the decoration comes from the time of Stanislaus Augustus and is linked with outstanding personalities of his court. On the wall opposite the entrance to the King's Dressing Room, two paintings by Bellotto have been hung: Colonel Koenigsfels teaches Prince Jozef Poniatomski to Ride and A Stable-boy Leading a Horse. On the window wall, bronze casts after original plaster models from Stanislaus Augustus's collection have been placed on plinths. The busts by André Le Brun represent people closely associated with the King, namely, August Fryderyk Moszyński, the Grand Master of the Pantry, a famous patron of art and the King's adviser in artistic matters; Karol Susson, the Royal upholsterer; Michał Bergonzoni, his doctor, and Szymon Bogumil Zug, an architect who worked for Stanislaus Augustus amongst other patrons. On the wall adjacent to the Dressing Room there are paintings by King Stanislaus Augustus's grant-holders: Aleksander Kucharski and Anna Rajecka. The furniture is complemented by a Rococo commode with a French clock made in Paris in 1749 placed on it, two sets of cobalt vases produced in the Royal Belvedere factory in the 1780s, late eighteenth century Polish rugs and chairs in the English style of the same period. The room is illuminated by a Venetian glass chandelier, of the mid-eighteenth century. The only reconstructed items are the two sconces over the fireplace.

The other solution consists in the adaptation of the original furnishing from a different historical building so that the original function of interior is emphasized. This method was employed while working out the architectural design and a programme of decoration for the complex of the so-called Chamberlain's Rooms. For this purpose Rococo panelling (hitherto in the National Museum in Warsaw, but originally in the Czartoryski Palace, later in the Tarnowski Palace in Warsaw) has been installed and hung with French tapestries produced at the Aubusson workshop. The parlour is illuminated with the original candelabra and sconces, likewise originating from the same source.

\section{The Fourth Group of Interiors}

In the course of the present reconstruction of the Castle rooms, a few interiors have been created which did not previously exist in their present forms (viz. the Oval staircase near the Ball Room, the staircase near the Theatre Hall, and the gallery near the Chamber of the Council) or were created shortly before 1939. Because they are situated in the sequence of historic rooms, it has been decided that their character should be in keeping with the adjacent rooms, and their furnishing has been so designed as to match the functional character of the interiors, this is demonstrated, for instance, by the corridor behind the Former Audience Room and Bedroom. From the mid-eighteenth century until the 1920s, the space of the present corridor was divided into three independent service rooms. In the course of conservation work carried out in the Castle in the 1920s, the partititon walls were removed, which resulted in the re-emergence of a long corridor joining the Vestibule with the Canaletto Room. At present, reverting to the pre-war arrangement, a kind of long gallery has been created. The wall opposite the windows is hung with tapestries woven with oriental motifs, and along the walls are bronze casts on stucco plinths. They are taken from plaster casts formerly in Stanislaus Augustus's collection and represent Izabella Czartoryska née Fleming; Józefa Amalia Potocka née Mniszech; Magdalena Agnieszka Sapieha née Lubomirska; Konstancja Tyskiewicz née Poniatowski; Mlle Le Brun, the sculptor's daughter; and Jan Emanuel Gilibert, botanist and Professor of Wilno University. A bust of 
King Stanislaus Augustus has been placed in the recess on the window wall. The only reconstructed items are the lanterns made according to late eighteenth century models.

\section{Conclusion}

In the reconstructed rooms of the Royal Castle in Warsaw there are two classes of objects, namely, original and reconstructed. The former come from the original Castle collection, from the collection of the National Museum in Warsaw, from purchases made by the Museum for the Castle or donations made to the Citizens' Committee for the Rebuilding of the Royal Castle in Warsaw. They have been restored and some minor losses have been replaced. Original objects will altogether total about 70 per cent of the overall furnishing, whereas the remaining 30 per cent will have been reconstructed. Although the latter constitutes only a small part of the furnishing of the Castle interiors, they will have been the most difficult task in the course of the reconstruction. While working out the furnishing programme, we have tried to reduce reconstructed furniture to a bare minimum, and it has been introduced principally in four situations: first, when in order to furnish a room a set of identical objects was necessary, e.g. a set of chandeliers, sconces, stools, banquettes, picture frames, plinths on which to mount sculptures, cloth for upholstery; secondly, when the surviving original sets of objects had to be complemented so as to reach the number of items necessary for the furnishing of a room; thirdly, when a missing object had to be re-created because it was closely connected with the character of a room and important for the stressing of its former function (as in the Former Audience and Throne Room where the backs and the canopies of the thrones have to be re-created; in the King's Bedroom where the King's bed has been reconstructed and the Conference Room where the settee will have been reconstructed; and lastly, the large ceiling paintings being redone in the Former Audience Room, the Ball Room and the Marble Study).

In addition to what had been set out above, the design and decoration of a few interiors refers back to old architectural forms and they have been furnished with items echoing in their design seventeenth or eighteenth century forms (this applies mainly to the lighting fittings). These interiors, which derive their shapes from the historic structure, no longer perform their original function but have acquired new ones in accordance with present-day requirements. This applies to the cloakroom complex in the cellars, the rooms intended for the display of Jan Matejko's works or the Treasury interiors on the second floor.

Exceptional is the complex of three rooms which made up the former apartment of Stefan Zeromski, going far beyond the system of interiors here presented. By a happy coincidence, a piece of the wall with a window has survived from the great writer's flat and was incorporated into the structure of the reconstructed Castle in 1971. This fragment, together with the window from Żeromski's room was almost a symbol of the will to rebuild the Royal Castle in Warsaw. Zeromski's association with the Castle will be immortalized: the flat in which he lived and wrote will be reconstructed on the basis of the descriptions provided by the writer's wife and daughter and in accordance with old photographs. ${ }^{2}$

\section{Notes}

1. Dr. Andrzej Rottermund's article, translated from the Polish, is a revised version of that originally published as

'Problemy Wnętrz Zamku Królewskiego w Warszawie', Rocznik Warszamski, XV, 1979, pp. 271ff. (Ed.)

2. In the course of final work on the furnishing of the Castle small changes may occur with regard to decoration of individual rooms in comparison with the programme outlined in the present article. The ground floor rooms have been installed and it is hoped that it will be possible to open them to the public in the Spring of 1982. The first floor will follow in 1983 and the Ball Room will possibly be opened to the public in 1984. 